\title{
Impact of Corporate Governance on Financial Performance: Karachi Stock Exchange, Pakistan
}

\author{
Aon Waqas Awan (Corresponding author) \\ Departament d'Economia Aplicada, Universitat de les Illes Balears \\ Carretera Valldemossa, Palma de Mallorca, Illes Balears, Spain \\ School of Business Administration, Shaheed Benazir Bhutto University \\ Shaheed Benazirabad, Postal Code: 67450, Sindh, Pakistan
}

Tel: 0092-333-682-0133Ｅ-mail: a-w.awan@uib.eu

Javed Ahmed Jamali (Principal author)

School of Business Administration, Shaheed Benazir Bhutto University

Shaheed Benazirabad, Postal Code: 67450, Sindh, Pakistan

Tel: 0092-307-2121382Ｅ-mail: javed_jamali@gmail.com

Received: July 24, 2016 Accepted: August 17, 2016

doi:10.5296/ber.v6i2.9772 URL: http://dx.doi.org/10.5296/ber.v6i2.9772

\begin{abstract}
The aim of the research is to understand the impact of corporate governance on financial performance of listed companies on Karachi Stock Exchange Pakistan. Data was collected from forty two companies from different sectors like, insurance, banking, investment banking, and sugar industries. Study includes variables like profit margin $\&$ return on equity as a dependent (profitability) and board size, audit committee, annual general meetings \& chief executive office (corporate governance). Using Pooled OLS, the result of the study proved those board size and audit committees have positive relationship with Profit margin and Return on Equity, if any independent variable changes it also stimulus the positively changing impact on Return on Equity (ROE) and Audit Committee (AC). This research offers imminent guidelines to the policy and decision makers in any type of firms to take good decision to set their firms hierarchy system.
\end{abstract}

Keywords: Corporate Governance, Profit Margin, Return on Equity, Board Size, Audit Committee 


\section{Introduction}

The current study explores the impact of corporate governance on financial performance. As financial performance has undeviating connection with the corporate governance. Promoting corporative governance has been primary concern for the companies of developed countries such as, United Kingdom, United State, and Netherland. It has more focus on the financial community through corporate governance. As investment institutions have a view level of corporate governance in corporate sectors that plays very important role in investment policies. Gompers et al. (2003) supported that corporate governance is very important factor for companies' profitability; long term and max over. The situation is also responsible to enhance the image of the companies' i.e. UK.

In normally speaking that there are two main reasons, due to which corporate governance increase in number of investors. First, the large numbers of the investors they think that the good governance firms are less risky. Secondly, they are spreading owner rate of return, which formulate them more valuable. Macking and Jensen (1976) denote that good governed firms have most capable function with high cash flow stream in future. Every firm of United Kingdom and European Monitory Union were grade on the behalf of their corporate governance. The Twenty percent of European Monitory Union companies used the maximum corporate governance and they are considered as "good governor portfolio". In comparison to this, twenty percent bottom companies are considered as "Bad governance portfolio".

Many studies displayed that corporate governance play very important role during crisis, e.g. during global financial crisis only the firms that sustain were with good corporate governance rating Joh, S. W. (2003) used 5,829 Korean firms subject to outside auditing during the pre-crisis period of 1993-1997; he had selected the Korean case for the following reasons. Joh, S. W. (2003) has argued that Korea's poor corporate governance system were the cause of 1997 crisis. Moreover, the Korean economy can be characterized by the prevalence of business groups chaebPooled OLS ${ }^{1}$. ChaebPooled OLS consist of legally independent, horizontally and vertically distributed firms. According to Joh (2001a) more than sixty percent of Korean firms subject to outside auditing belong to business groups (including small ones). Financial crises of July 1997, were shown in many East Asian markets, the result of these crises emerging markets were effected, and were increased in the Middle East, Lation American and Eastern Europe. Investors of other countries also discovers their exposed results, when many large countries exchange rate were decline then recipient stock market were also go to slip heap and almost in the crisis period all the emerging markets were facing in troubling position. Due to this, the rate of exchange was declined and market also declines.

Clarification during the crisis period pose the questions such as why some countries firms give the better performance from others, how they utilized their legal institution and firms structure of corporate governance to control their minority shareholders. Although comparison of country specific and cross-country studies is concerned, many cross-country

${ }^{1}$ Chaebol is the largest business group of Korean.

${ }^{2}$ Organisation for Economic Cooperation and Development 
studies do not justification the significant country-specific laws that affect procedures of ownership and control rights. Consider the Korean law requiring 'shadow voting' and a obligatory caring offer, for example Korean financial institutions were officially forbidden from affecting outcomes in corporate voting decisions "shadow voting". In addition to this, anyone acquiring $25 \%$ of a firms share had to tender an offer on at least $50 \%$ of these shares.

During the financial crisis, it has been renowned that the companies with have weak corporate governance structure faces more problems that the strong one. There are many studies like (The Onset of the East Asian Financial) Crisis conducted on 1997-98 crisis period. Financial crisis 1997 mostly hit the rapidly growing economies in financial history of the world Yung-Chul Park (1996).

In 2007-2008 the financial crisis normally examined as the most horrible financial crisis as the Great Depression of the 1930s. The crisis not only resulted in the fall down of well-known financial institutions such as Lehman Brothers, but as well stop the progress of worldwide credit markets and necessary unparalleled government involvement worldwide. For example, U.S government launched TARP in October 2008, to acquire or insure up to $\$ 700$ billion of assets from financial institutions. In the similar month, the British government announced a bank position free package totaling $£ 500$ (\$740) billion in loans and guarantees. Motivated by the consequence of the 2007-2008 financial crises, an emerging body of literature has challenged to make out and check the global roots of the crisis. That literature proposes that a combination of macroeconomic factors such as slack monetary policies and complex securitizations have contributed to the crisis (Taylor, 2009). Since macroeconomic factors only can incompletely explain why some firms performed substandard than others during the crisis period (e.g., U.S. versus Swiss financial firms), it is key to examine how firm-level strategies have influenced firm performance during the financial crisis. Two form of firm-level policies that radically affected the magnitude of shareholder losses during the crisis have received substantial attention from academics and investors: (1) risk management before the crisis and (2) equity capital going to in the peak during the crisis. As explained by Brunnermeier (2009), the relationship between banks' exposure to subprime mortgages and their reliance on short-term borrowing had a significant impact on the performance of financial firms during the crisis period. Financial firms' threat or risk management sooner than the crisis and capital lift up activities during the time of the crisis.

According to Iqbal and Javed (2006) explore the effect of C.G on Pakistani firms' performance. Pakistani firms enhance all element of C.G, and proposed that good C.G measured low production and bad C.G management practices by clear open and clarity standards. Khanna et al., 1996, 1997, 1998, 1999 and Pankaj 1996 they suggested that the literature of corporate governance in Pakistan is a lot thin, and have the lack of research culture in Pakistani institutions and firms areas. Roe, 2002 defined that the Culture may change as corporate structures change, however if a particular position of cultural behavior is so much deeply embedded in the society, that it fits many firms/institutions, then it will not change if it is impeding the objectives of one institution. In Pakistan the changing of in cultural traits cannot occur if the regulatory institutions desire the change only. In the last few years in Pakistan, corporate governance has become an important area of research. Cheema 
(2003) suggested that corporate governance be able to play a significant task for Pakistan to pull towards foreign direct investment and saving through capital provided the corporate governance system is compatible with the objective of raising external equity capital through capital markets. The structure of corporate governance of Pakistan is characterized as concentrated family control, interlocking directorships, cross-shareholdings and pyramid structures.

\subsection{Study Background}

Many international companies of different countries like, (United States, Germany, Japan, and the United Kingdom) have some of the best corporate used the corporate governance tool to manage or controlled their business Barca (1995). However, in least developed countries like Pakistan there is no awareness about the corporate governance, as we know that corporate governance is consider one of the important factor for performance. According to Awan (2012), only 55\% organizations in Pakistan are properly focusing on corporate governance.

\subsection{Research Objectives}

Corporate governance is the structure of firm which is used by many companies in developed countries. The structure implements the role to manage or to control their required business activities. The board of director or head of the department are responsible to utilize the corporate governance tool in their business. According to Muhammad Akram Naseem et al. (2011) practice of strong corporate governance facilitates the firms or institutions to get better results and provide broad focus on investments. Thus, as a fact in order to sustain shareholders rights, access to the official requirements strong corporate governance facilitate a widespread community to one's own firms' goals. So, before going to embark upon the business strategies used in our country and to scrutinize the different strategies used for beneficial business, the current study sets following research objectives.

Following are our research study research objectives:

- To measure the financial performance and corporate governance of listed Karachi Stock Exchange companies.

- To examine the extended relationship between the performance and corporate governance of companies.

\section{Methodology}

The current study is depended on secondary information. So, for investigation of proposed objectives study collected the information from the reports of companies which were published in the shape of audited financial statements like documentary, websites of companies and other secondary sources, etc. The study used (POOLED OLS) regression model to investigation or interpretation the results.

\subsection{Data Collection}

Data was collected from Audited Financial Statements and analysis of joint stock companies, 


\section{Macrothink}

Business and Economic Research

ISSN 2162-4860

2016, Vol. 6, No. 2

which are listed on KSE. The period was selected for this study was 10 years effected from 2005-2014. The Study designated the four main sectors like, Insurance companies, banking, investment banking and sugar industries of KSE 100 index which are round about containing forty two companies. The reasons for selecting this proportion are the availability of time.

\subsection{Theoretical Framework}

The theoretical framework for the study is shown in figure 2.1. The study measures the impact of corporate governance variables on financial performance of the firm.

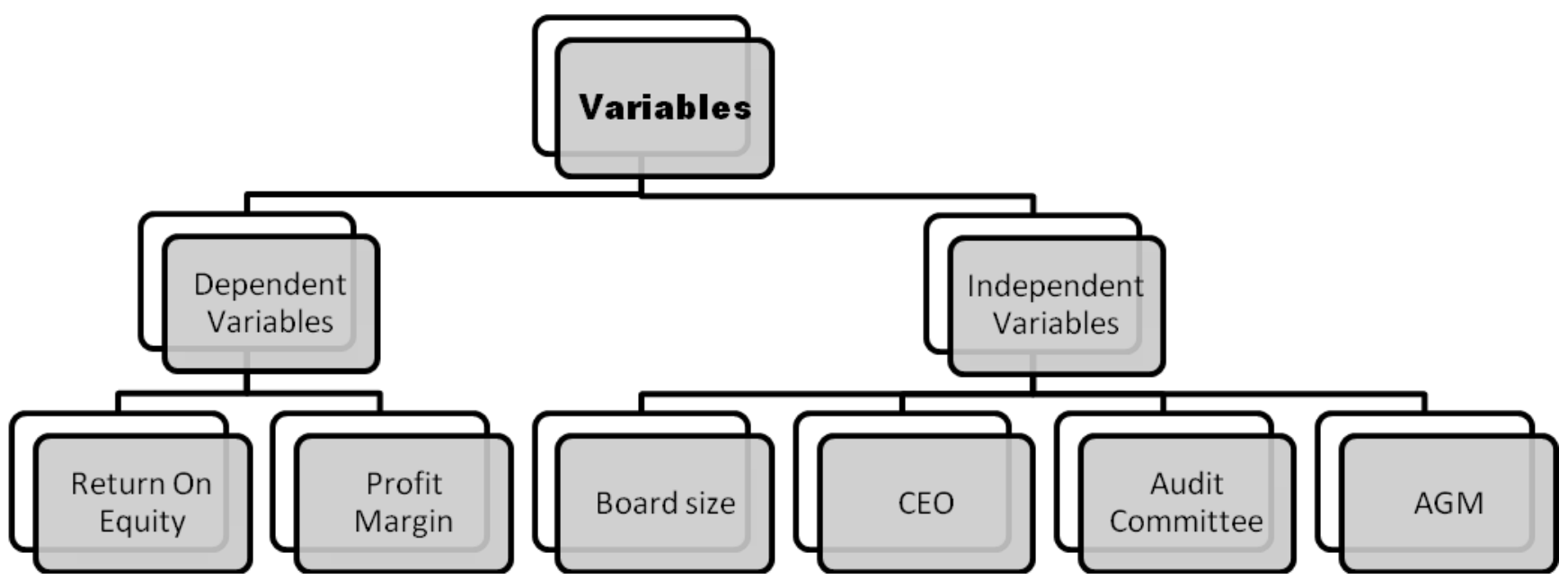

Figure No. 2.1.

\section{Variables}

Following are the independent variables of this study;

Board Size: It is estimated that limitation of board size is very healthy to get better firm performance since the benefits by larger board of directors increased supervise are be more important than by the inferior announcement and decision-making of larger groups Lipton and Lorsch (1992);. Brown and Caylor (2004) denoted that between 6 and 15 firms with board sizes have higher returns on equity as well as higher net profit margins than do firms with other board sizes. Eisenberg et al. (1998) shown that when board size increases, management and communication problems increase.

CEO (Chief Executive Officer): There are two main important positions in any type of firms like, first Chairman and second Chief Executive Officer. These two positions CEO and chairman manipulate on firms' performance. The reason is that the firms problems are in complex when the single person who hold both positions. According to the Yermack (1996) denoted that when CEO and Chairman are commonly separated firms are more valuable, by analyzing the sample of 452 U.S. public firms between (1984 and 1991). Core, et al. (1999) denoted that the CEO recompense is substandard while the CEO and chairmen positions are separate. Brown and Caylor (2004) highlighted firms got more advantage when the CEO and board chair person positions are separate.

Audit committee: It provide as a postponement link in the communication system between 


\section{Macrothink}

Business and Economic Research

ISSN 2162-4860

2016, Vol. 6, No. 2

internal and external auditors and the board of directors, their actions includes evaluation of designated auditors. Klein (2002) reported that negative correlation between the audit committee and earning. Mansi and Anderson (2004) denoted that completely independent audit committees have very low debt financing costs.

AGM (Annual General Meeting): The Annual General Meeting is the extremely important and most authoritative body of any organization. The AGM is the fundamental decision maker. The AGM provides the organization direction in strategy when dealing with the goals. The AGM come into sight to have emerged as an accountability mechanism in early English local government and joint stock firms. (Cordery, 2005) denoted that there is a scarcity of investigate on its effectiveness. Extant research has considered shareholder activism in AGMs (e.g. Marens 2002; Marinetto, 1998) and whether this activism is empirically successful (Karpoff, Malatesta, \& Walkling, 1996).

\subsection{Hypothesis}

Following are the hypothesis of the study:

H1: Board Size has positive effect on Return on Equity \& Profit Margin

H2: Audit Committee has negative effect on Return on Equity \& Profit Margin

H3: Chief Executive Officer has negative effect on Return on Equity \& Profit Margin

\section{Results}

Corporate governance plays very important role in any firm's financial performance. The study implies the impact of corporate governance on financial performance of companies listed on Karachi Stock Exchange of "Pakistani". By using the 42 companies data, which were collected from four different sectors like (Insurance companies, banking, investment banking and sugar industries).

Part One Regression Model of Profit Margin

Model 1. POOLED OLS, using observations 1-42

Dependent variable: PM

Heteroscedasticity-robust standard errors, variant HC1 
Table 1. Regression of Profit Margin

\begin{tabular}{|c|c|c|c|c|}
\hline & Coefficient & Std. Error & t-ratio & p-value \\
\hline Const & -1.75506 & 1.08117 & -2.6233 & $0.0130 * *$ \\
\hline $\mathrm{BS}$ & 0.119171 & 0.0816758 & 2.4591 & $0.0430 * *$ \\
\hline $\mathrm{AC}$ & 0.21149 & 0.402603 & 2.5253 & $0.0256 * *$ \\
\hline Mean dependent var & 0.173154 & \multicolumn{2}{|c|}{\begin{tabular}{l|l} 
& S.D. dependent var
\end{tabular}} & 1.106530 \\
\hline Sum squared resid & 48.50513 & \multicolumn{2}{|c|}{ S.E. of regression } & 1.144967 \\
\hline R-squared & 0.033778 & \multicolumn{2}{|c|}{ Adjusted R-squared } & -0.070679 \\
\hline $\mathrm{F}(4,37)$ & 4.997917 & \multicolumn{2}{|c|}{ P-value(F) } & 0.040971 \\
\hline Log-likelihood & -62.61942 & \multicolumn{2}{|c|}{ Akaike criterion } & 135.2388 \\
\hline Schwarz criterion & 143.9272 & \multicolumn{2}{|c|}{ Hannan-Quinn } & 138.4235 \\
\hline
\end{tabular}

The study calculated profit margin and return on equity ratios in order to determine the behavior of independent variables study created POOLED OLS model to apply regression and different types of statistical tests. Results were exhibits on the basis of coefficient values, by determining the Profit margin, R-squired of profit margin. Table no. 1 and 2 clearly demonstrate that the value of dependent variable Profit margin is 0.03 which shows that dependent variables explain 3\% all independent variables and Table no. 2 coefficient of return on equity is 0.129 , which shows that dependent variables explain 12.9 all independent variables.

Part Two Regression Model of Profit Margin

Model 2: POOLED OLS, using observations 1-42

Dependent variable: ROE

Heteroskedasticity-robust standard errors, variant $\mathrm{HC} 1$

Table 2. Regression Model of RoE

\begin{tabular}{|l|l|l|l|l|l|}
\hline & Coefficient & Std. Error & t-ratio & p-value & \\
\hline Const & -0.379211 & 0.167348 & -2.2660 & 0.0291 & $* *$ \\
\hline BS & 0.0514626 & 0.0185272 & 2.7777 & 0.0084 & $* * *$ \\
\hline AC & 0.207832 & 0.0998754 & 2.0809 & 0.0441 & $* *$ \\
\hline Mean dependent var & 0.076040 & & S.D. dependent var & 0.206099 \\
\hline Sum squared resid & 1.516156 & & S.E. of regression & 0.197169 \\
\hline R-squared & 0.129424 & & Adjusted R-squared & 0.084779 \\
\hline $\mathrm{F}(2,39)$ & 4.338942 & & P-value(F) & 0.019887 \\
\hline Log-likelihood & 10.15590 & & Akaike criterion & -14.31181 \\
\hline Schwarz criterion & -9.098797 & & Hannan-Quinn & -12.40103 \\
\hline
\end{tabular}

On another hand, study applies the F-test upon the data to acknowledge the justification for 
the implementation of fitness model. Results reported the Value of F-test of profit margin is 4.997. Further, the value of $F$ value is compared with tabular value of $(4,37)$ which is in the range of 3.81742. The value of F-test is clearly greater then tabular value. On contrary to this, the value of F-test for Return on equity is $4.3389 \mathrm{~F}(2,39)$ which is also greater than F-test. Thus on the basis of this we can safely claim that adopted model is fit for the current study.

Study finds the coefficient of profit margin. Coefficient of board size is 0.119 , which shows that the positive relationship between profit margin and board size. Coefficient of Audit Committee is 0.211 ; it shows that positive relationship of audit committee and profit margin. Finding the coefficient of return on equity, coefficient of board size is 0.051 , which also shows that positive relationship between board size and return on equity and the coefficient of audit committee is 0.2078 , which shows that audit committee and return on equity has positive relationship.

Study used the T-test for analyzing coefficients. The value of board size of profit margin in t-test is 2.4591 , study compared this value in tabulated value $(0.05,41)$ is 1.684 . So the value of t-test is greater than tabulated value, study has rejected null hypotheses. The value of audit committee of profit margin t-test is 2.525 . This study compared in tabulated value is 1.684; tabulated value is lower than t-test value so study has reject null hypotheses. The value of board size of return on equity is 2.777 this value compared with tabulated value 1.684 , the value of t-test is greater than tabulated value so in this case study has rejected null hypotheses. Value of audit committee of return on equity is 2.0809 , this value compared with tabulated value which is 1.684 . the value of t-test is greater than tabulated value so study has rejected null hypotheses.

Table 3. Breusch-Godfrey Serial Correlation LM Test

\begin{tabular}{|l|l|l|l|}
\hline \multicolumn{4}{|c|}{ Breusch-Godfrey Serial Correlation LM Test } \\
\hline F-statistic & 1.498124 & Prob. F(2,37) & 0.2368 \\
\hline Obs*R-squared & 3.146355 & Prob. Chi-Square(2) & 0.2074 \\
\hline
\end{tabular}

This study used the Serial Correlation LM Test to find the correlation between dependent variables and independent variables. So measured the value of prob.Chi-square(2) is 0.2074, compare this value in significant value (0.05) the prob.Chi-square(2) is greater than significant value so in this case variables are no correlation with each other. So study has rejected null hypotheses.

Table 4. Breusch-Pagan-Godfrey

\begin{tabular}{|l|l|l|l|}
\hline Heteroskedasticity Test: Breusch-Pagan-Godfrey \\
\hline F-statistic & 0.081268 & Prob. F(2,39) & 0.9221 \\
\hline Obs*R-squared & 0.174312 & Prob. Chi-Square(2) & 0.9165 \\
\hline Scaled explained SS & 0.296583 & Prob. Chi-Square(2) & 0.8622 \\
\hline
\end{tabular}




\section{$\triangle$ Macrothink}

Business and Economic Research ISSN 2162-4860

Finally, this test used for residuals heteroscedastic test, either, data is normally distributed or not. Study has to use Breusch test, the value of prob.Chi-square (2) is 0.9165 and prob.Chi-square (2) is 0.8622 compare these value in significant value (0.05) the prob.Chi-square (2) are greater than significant value so in this case variables residuals are normally distributed. So, this study has rejected null hypotheses.

\section{Conclusion}

The most important purpose for study was to determine the impacts of corporate governance to measure the financial performance of firms of Karachi Stock Exchange between the periods of (2005-2014).

Using the data of companies listed on Karachi Stock Exchange; from four sectors like, insurance companies, banking, investment banking and sugar industries. Study finds that the good corporate governance practices on firm's financial performance. The role of this study is essential for mutually academic researchers and business managers. This study boosts the strength of prior studies on relationship between corporate governance and financial performance and makes a number of important assistance to the literature. This study finds that the board size, audit committee has the positive relationship with profit margin and return on equity.

\section{References}

Anderson, R. C., Mansi, S. A., \& Reeb, D. M. (2004). Board characteristics, accounting report integrity, and the cost of debt. Journal of accounting and economics, 37(3), 315-342. http://dx.doi.org/10.1016/j.jacceco.2004.01.004

Awan, A. W., Kamal, T., Rafique, M., Khan, S., \& SZABIST, I. (2012). Corporate social responsibility in Pakistan economy. Business \& Economic Review, 2(1), 1-31.

Barca, F. (1995). On corporate governance in Italy: issues, facts and agenda. Facts and Agenda (September 1995).

Brown, L. D., \& Caylor, M. L. (2004). Corporate governance and firm performance. Available at SSRN 586423.

Brunnermeier, M. K. (2009). Deciphering the liquidity and credit crunch 2007-2008. The Journal of economic perspectives, 23(1), 77-100.

http://dx.doi.org/10.1257/089533009797614162

Cheema, A. (2003) Corporate Governance in Pakistan: Issues and Concerns. The NIPA Journal, 8(2), 7-19.

Core, J. E., Holthausen, R. W., \& Larcker, D. F. (1999). Corporate governance, chief executive officer compensation, and firm performance.Journal of financial economics, 51(3), 371-406. http://dx.doi.org/10.1016/S0304-405X(98)00058-0

Dar, L., Akmal, A., Naseem, M. A., \& din Khan, K. U. (2011). Impact of stress on employees job performance in business sector of Pakistan. Global journal of management and business 
research, 11(6).

Eisenberg, T., Sundgren, S., \& Wells, M. T. (1998). Larger board size and decreasing firm value in small firms. Journal of financial economics, 48(1), 35-54.

http://dx.doi.org/10.1016/S0304-405X(98)00003-8

Gompers, P. A., Ishii, J. L., \& Metrick, A. (2001). Corporate governance and equity prices (No. w8449). National bureau of economic research. http://dx.doi.org/10.3386/w8449

Javed, A. Y., Iqbal, R., \& Hasan, L. (2006). Corporate Governance and Firm Performance: Evidence from Karachi Stock Exchange [with Comments]. The Pakistan Development Review, 947-964.

Jensen, M. C., \& Meckling, W. H. (1976). Theory of the firm: Managerial behavior, agency costs and ownership structure. Journal of financial economics, 3(4), 305-360.

http://dx.doi.org/10.1016/0304-405X(76)90026-X

Joh, S. W. (2003). Corporate governance and firm profitability: evidence from Korea before the economic crisis. Journal of financial Economics, 68(2), 287-322.

http://dx.doi.org/10.1016/S0304-405X(03)00068-0

Karpoff, J. M., Malatesta, P. H., \& Walkling, R. A. (1996). Corporate governance and shareholder initiatives: Empirical evidence. Journal of Financial Economics, 42(3), 365-395. http://dx.doi.org/10.1016/0304-405X(96)00883-5

Khanna, M., \& Damon, L. A. (1999). EPA's voluntary 33/50 program: Impact on toxic releases and economic performance of firms. Journal of environmental economics and management, 37(1), 1-25. http://dx.doi.org/10.1006/jeem.1998.1057

Klein, A. (2002). Audit committee, board of director characteristics, and earnings management. Journal of accounting and economics, 33(3), 375-400.

http://dx.doi.org/10.1016/S0165-4101(02)00059-9

Lipton, M., \& Lorsch, J. W. (1992). A modest proposal for improved corporate governance. The business lawyer, 59-77.

Marinetto, M. (1998). The shareholders strike back: issues in the research of shareholder activism. http://dx.doi.org/10.1080/09644019808414412

Morrison, D., Cordery, J., Girardi, A., \& Payne, R. (2005). Job design, opportunities for skill utilization, http://dx.doi.org/10.1080/13594320444000272

Park, Y. C. (1996). Yung Chul Park: East Asian Liberalization, Bubbles, and the Challenge from China. Brookings Papers on Economic Activity, 1996(2), 357-371. DOI: $10.2307 / 2534626$

Roe M (2002). Some Differences in Company Structure in Germany, Japan and the United States. Yale Law J., 102(7), 1927-2003. http://dx.doi.org/10.2307/796856

Taylor, J. B. (2009). The financial crisis and the policy responses: An empirical analysis of 


\section{Macrothink}

Business and Economic Research

ISSN 2162-4860 2016, Vol. 6, No. 2

what went wrong (No. w14631). National Bureau of Economic Research.

Yermack, D. (1996). Higher market valuation of companies with a small board of directors. Journal of financial economics, 40(2), 185-211.

http://dx.doi.org/10.1016/0304-405X(95)00844-5

\section{Copyright Disclaimer}

Copyright for this article is retained by the author(s), with first publication rights granted to the journal.

This is an open-access article distributed under the terms and conditions of the Creative Commons Attribution license (http://creativecommons.org/licenses/by/3.0/). 